\title{
Pengaruh Kepribadian Introvert Terhadap Stres Kerja
}

\section{Erwin Munawar, 2Rusman Frendika, 3Firman Shakti}

Prodi Manajemen, Fakultas Ekonomi dan Bisnis, Universitas Islam Bandung, Indonesia.

*erwinmunawar01@gmail.com,2rusmanf82@gmail.com,3firmanshakti83@gmail.com

\begin{abstract}
This study was conducted based on the phenomenon that occurs that there are problems related to the Influence of Introvert Personality on Employee Work Stress, so this study aims to find out the Influence of Introvert Personality On Work Stress On Employees, as well as analyze how much influence Introvert Personality (independent variable) on Work Stress (dependent variables) in PT. Madani Mekaar National Capital. Sampling in this study using sampling techniques and Saturated Sample Techniques. This study uses a method or type of Casual Associative research that uses a Descriptive Verificative approach with the number of respondents as many as 36 employees of PT. Madani Mekaar National Capital, using field research data collection techniques and literature. The statistical test used is simple Linear Regression Test. Then the results of this study can be concluded that Introvert Personality does not have a positive and significant effect on Work Stress on employees of PT Permodalan Nasional Madani Mekaar.
\end{abstract}

Keywords: Introvert Personality, Work Stress

Abstrak. Penelitian ini dilakukan berdasarkan fenomena yang terjadi bahwa terdapat masalah yang berkenaan dengan Pengaruh Kepribadian Introvert terhadap Stres Kerja Karyawan, sehingga penelitian ini bertujuan untuk mengetahui Pengaruh Kepribadian Introvert Terhadap Stres Kerja Pada Karyawan, serta menganalisis seberapa besar pengaruh Kepribadian Introvert (variabel independen) terhadap Stres Kerja (variabel dependen) di PT. Permodalan Nasional Madani Mekaar. Pengambilan sampel dalam penelitian ini menggunakan teknik sampling dan Teknik Sampel Jenuh. Penelitian ini menggunakan metode atau jenis penelitian Asosiatif Kasual yang menggunakan pendekatan Deskriptif Verifikatif dengan jumlah responden sebanyak 36 orang karyawan PT. Permodalan Nasional Madani Mekaar, menggunakan teknik pengumpulan data penelitian lapangan dan penelitian kepustakaan. Uji statistik yang digunakan yaitu Uji Regresi Linear Sederhana. Kemudian hasil penelitian ini dapat disimpulkan bahwa Kepribadian Introvert tidak berpengaruh positif dan signifikan terhadap Stres Kerja pada karyawan PT Permodalan Nasional Madani Mekaar.

Kata Kunci: Kepribadian Introvert, Stres Kerja 


\section{A. Pendahuluan}

Karyawan terkadang bahkan sering dihadapkan dengan berbagai masalah dalam perusahaan, sehingga terkena stres. Stres dalam pekerjaan diartikan sebagai tekanan yang dirasakan oleh karyawan karena tugas pekerjaannya tidak selesai. Artinya, karyawan tidak mampu beradaptasi dengan tempat kerja yang semakin dinamis dan terkadang bertentangan dengan yang lainnya, seperti perbedaan pendapat, beban kerja yang berlebih dan masih banyak yang lainnya sehingga membuat stres menjadi faktor yang hampir tidak mungkin dihindari dalam pekerjaan. Konflik antar karyawan merupakan salah satu pemicu stres yang terjadi di tempat kerja, hal ini biasanya disebabkan oleh perbedaan pendapat, tentunya perbedaan pendapat ini dikarenakan adanya perbedaan kepribadian dari para karyawan tersebut yang memang tidak satu pandangan dalam menghadapi atau menyelesaikan suatu hal.

Kepribadian adalah tingkah laku seseorang yang membuat dirinya berbeda dengan oranglain, seperti karakternya, tingkah lakunya, minatnya, atau pendiriannya. Secara umum, kepribadian seseorang dibedakan menjadi 2 tipe, yaitu : (1) introvert dan (2) ekstrovert. Individu tipe introvert cenderung stres apabila dihadapkan pada persoalan yang membuat ia terancam atau tertekan dalam berhubungan dengan oranglain. Beda halnya dengan tipe ektrovert yang begitu senang apabila berhubungan dengan oranglain, contohnya dalam komunikasi.

Mengelola karyawan di dalam perusahaan bukanlah hal yang mudah, karena karyawan memiliki kepribadian yang berbeda, serta mempunyai keinginan, pikiran, perasaan, dan latar belakang yang berbeda pula yang mereka bawa kedalam perusahaan. Adanya perbedaan kepribadian, pendapat, dan pemikiran, dapat menimbulkan suatu stres kerja di dalam perusahaan dan hal ini tidak dapat dihindari oleh siapapun. Stress yang terjadi di dalam suatu perusahaan secara umum akan memberikan pengaruh signifikan terhadap target pekerjaan yang seharusnya dapat diselesaikan dengan optimal menjadi tidak optimal.

Berdasarkan penelitian yang dilakukan sebelumnya oleh dimitru tentang The Relationship Between Stress and Personality Factors dapat disimpulkan bahwa seseorang dengan kepribadian introvert rentan mengalami stres dalam pekerjaanya (Dimitru dkk, 2012).

Berdasarkan hasil wawancara yang dilakukan dengan kepala cabang PT PNM Mekaar Tanjungsari, karyawan yang berkpribadian introvert rentan mengalami stres dalam melakukan pekerjaannya. Stres kerja yang dihadapi oleh para karyawan PT PNM Mekaar tersebut antara lain. Pertama dari segi fisik, karyawan mengalami stres karena pekerjaannya tidak dapat terselesaikan tepat waktu, sehingga membuatnya tidak bersemangat dan lelah untuk bekerja kembali karena saat pekerjaan tidak selesai, karyawan akan mendapatkan punishment dari perusahaan. Kedua, karyawan mengalami stres karena selalu bekerja dilapangan yang membuat tubuhnya drop/(sakit), sehingga dirinya cenderung memilih untuk tidak masuk kerja karena kondisinya sedang tidak baik. Ketiga dari segi mentalnya, karyawan mulai stres karena tidak siap dengan tekanan pekerjaan yang dihadapinya, sehingga membuat dirinya memilih jalan resign atau mengundurkan diri dari pekerjaanya karena ketidaksiapannya menghadapi tekanan.

Kemudian fenomena kepribadian introvert yang terjadi pada karyawan PT PNM Mekaar yang pertama, beberapa karyawan di perusahaan ini sulit menjalin hubungan dengan karyawan lainnya, pribadi introvert cenderung menghindari hubungan dengan karyawan lain, sehingga mengakibatkan pekerjaan tidak selesai tepat waktu karena hubungan yang tidak baik dengan karyawan lainnya. Kedua, beberapa karyawan tidak pandai dalam berkomunikasi, sehingga saat dirinya sedang drop/(sakit), ia langsung memilih untuk tidak masuk kerja daripada menceritakannya secara langsung kepada rekan atau atasannya. Ketiga, karyawan yang berkepribadian introvert cenderung menghindari resiko dalam pekerjaanya, sehingga saat pekerjaanya penuh resiko dan tidak sesuai dengan pandangannya akan membuat dirinya tertekan karena tidak siap menghadapi resiko dari pekerjaan tersebut.

Berdasarkan latar belakang yang telah diuraikan, maka perumusan masalah dalam penelitian ini antara lain :

1. Bagaimana kepribadian introvert karyawan pada PT PNM Mekaar ?

2. Bagaiamana stres kerja karyawan pada PT PNM Mekaar?

3. Seberapa besar pengaruh kepribadian Introvert terhadap stres kerja karyawan pada PT PNM Mekaar? 
Selanjutnya, tujuan dalam penelitian ini antara lain.

1. Untuk dapat mengetahui kepribadian introvert karyawan pada PT PNM Mekaar

2. Untuk dapat mengetahui bagaimana stres kerja karyawan pada PT PNM Mekaar

3. Untuk dapat mengetahui pengaruh kepribadian Introvert terhadap stres kerja karyawan pada PT PNM Mekaar

\section{B. Metodologi Penelitian}

Objek yang diteliti dalam penelitian ini adalah Kepribadian Introvert (X) dan Stres Kerja (Y) pada PT. PNM Mekaar yang merupakan bagian dari PT PNM (Persero). Responden dalam penelitian ini adalah karyawan dari PT. PNM Mekaar itu sendiri. Berdasarkan variabel-variabel tersebut maka penulis akan meneliti mengenai Pengaruh Kepribadian Introvert terhadap Stres Kerja pada Karyawan PT. Permodalan Nasional Madani Mekaar.

Kemudian berdasarkan latar belakang, rumusan masalah, serta tujuan penelitian, maka Jenis penelitian ini adalah penelitian asosiatif kausal. Menurut Sugiyono (2016:37), penelitian asosiatif kausal merupakan penelitian yang bertujuan untuk mengetahui ada dan tidaknya pengaruh atau hubungan antara variabel bebas terhadap variabel terikat dan apabila ada seberapa eratnya pengaruh atau hubungan serta berarti atau tidaknya pengaruh atau hubungan itu.

Penelitian ini menggunakan pendekatan deskriptif-verifikatif, karena penelitian ini berupaya mendeskripsikan dan menginterpretasikan pengaruh antara variabelvariabel yang akan ditelaah hubungannya serta tujuannya untuk menyajikan gambaran terstruktur, faktual, dan akurat mengenai fakta-fakta hubungan antara variabel yang diteliti.

Adapun tabel Operasional Variabel dalam penelitian ini :

Tabel 1. Operasional Variabel

\begin{tabular}{|c|c|c|c|c|c|}
\hline Variable & Dimeusi & Indilcator & Utaran & Skala & NoItem \\
\hline \multirow{4}{*}{$\begin{array}{l}\text { Repribadian } \\
\text { Introvert }(\mathrm{X})\end{array}$} & Socialibility & Hubungan & $\begin{array}{l}\text { Tinghat } \\
\text { Sosial }\end{array}$ & Ordinal & 182 \\
\hline & Liveliness & S1kap & Pendiam & Ordinal & $3 \& 4$ \\
\hline & Jocularity & Koruniasi & $\begin{array}{l}\text { Kaku/Tidak } \\
\text { Lancar }\end{array}$ & Ordinal & $5 \& 6$ \\
\hline & Inpulsivenss & Perilaku & Teratuf & Ordinal & $7 \& 8$ \\
\hline \multirow{2}{*}{$\begin{array}{l}\text { Stres Kerja } \\
\text { (Y) }\end{array}$} & Fisik: & Beban & Berat & Ordinal & $9 \& 10$ \\
\hline & Mental & Pikiran & Stabil & Ordinal & $11 \& 12$ \\
\hline
\end{tabular}

Metode pengumpulan data yang digunakan dalam penelitian ini menggunakan beberapa metode yaitu survey dengan kuisioner / angket dan studi kepustakaan. Serta populasi dan sampel dalam penelitian ini adalah karyawan PT PNM Mekaar dengan jumlah 36 karyawan, dimana peneliti memilih sampel berdasarkan tipe karakteristik kepribadian introvert.

Adapun teknik analisa yang digunakan dalam penelitian ini menggunakan uji instrumen seperti, uji validitas uji realibilitas dan uji normalitas, serta menggunakan uji hipotesis seperti regresi linear sederhana, uji R2 dan uji t.

1. H0 : $\beta 1=0:$ Kepribadian Introvert $(\mathrm{X})$ tidak berpengaruh terhadap Stres Kerja (Y) pada PT PNM Mekaar.

2. Ho : $\beta 1 \neq 0:$ Kepribadian Introvert $(\mathrm{X})$ berpengaruh terhadap Stres Kerja (Y) pada PT PNM Mekaar

Adapun hipotesis statistik dalam penelitian ini yaitu :

\section{Hasil Penelitian dan Pembahasan}

Penelitian ini dilakukan terhadap kayawan pada PT. Permodalan Nasional Madani Mekaar yang berjumlah 36 responden, untuk mengetahui seberapa besar pengaruh kepribadian introvert terhadap stres kerja pada karyawan. Angket penelitian sudah disampaikan dan diisi oleh responden dengan soal 12 butir pertanyaan, dengan rincian 8 pertanyaan untuk kepribadian 
introvert, dan 4 pertanyaan untuk stres kerja.

Berikut ini adalah beberapa hasil dari Uji Instrumen validitas dalam penelitian ini :

Tabel 2. Hasil Uji Validitas

\begin{tabular}{|c|c|c|c|c|}
\hline Variabel & Item Pertanyaan & $\begin{array}{c}\text { Corrected } \\
\text { Item } \\
\text { Pertanyaan } \\
\text { Total } \\
\text { Correlation }\end{array}$ & $\begin{array}{c}\mathbf{r} \\
\text { table }\end{array}$ & Ket. \\
\hline \multirow{6}{*}{$\begin{array}{l}\text { Kepribadian } \\
\text { Introvert } \\
\text { (X) }\end{array}$} & Kepribadian Introvert 3 & 0,803 & 0,329 & Valid \\
\hline & Kepribadian Introvert 4 & 0,803 & 0,329 & Valid \\
\hline & Kepribadian Introvert 5 & 0,682 & 0,329 & Valid \\
\hline & Kepribadian Introvert 6 & 0,816 & 0,329 & Valid \\
\hline & Kepribadian Introvert 7 & 0,572 & 0,329 & Valid \\
\hline & Kepribadian Introvert 8 & 0,350 & 0,329 & Valid \\
\hline \multirow{4}{*}{$\begin{array}{c}\text { Stres Kerja } \\
(\mathrm{Y})\end{array}$} & Stres Kerja 9 & 0,659 & 0,329 & Valid \\
\hline & Stres Kerja 10 & 0,713 & 0,329 & Valid \\
\hline & Stres Kerja 11 & 0,371 & 0,329 & Valid \\
\hline & Stres Kerja 12 & 0,371 & 0,329 & Valid \\
\hline
\end{tabular}

Dari tabel di atas dapat disimpulkan Dari keterangan tabel di atas dapat diketahui bahwa setiap item pertanyaan memiliki $r$ hitung $>$ dari $r$ tabel $(0,329)$ serta bernilai positif. Dengan demikian butir pertanyaan-pertanyaan tersebut dinyatakan valid. antara lain :

Adapun hasil kesimpulan uraian data dari variabel kepribadian introvert dan stres kerja

Tabel 3. Grafik Data Kepribadian Introvert

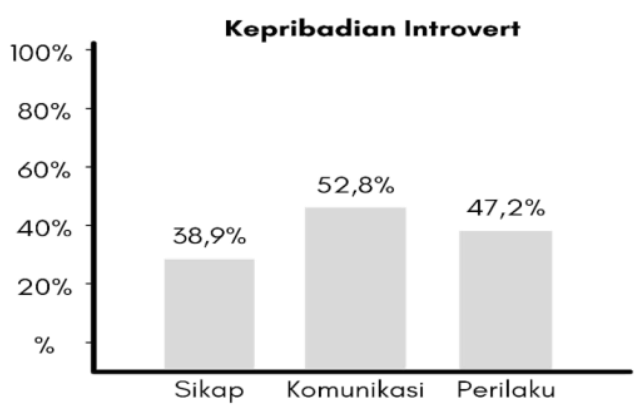

Berdasarkan tabel kesimpulan diatas, diperoleh skor persentase tertinggi dari masingmasing indikator dari variabel kepribadian introvert antara lain, indikator sikap sebesar 38,9\%, Komunikasi $52,8 \%$, dan perilaku 47,2\%. Maka dapat disimpulkan persentase tertinggi berada pada indikator komunikasi dengan nilai sebesar 52,8\%, dimana karyawan di PT. Permodalan Nasional Madani Mekaar yang berkepribadian introvert menyatakan bahwa komunikasi mereka dengan karyawan lainnya biasa saja ditempat kerja. 
Tabel 4. Grafik Data Stres Kerja

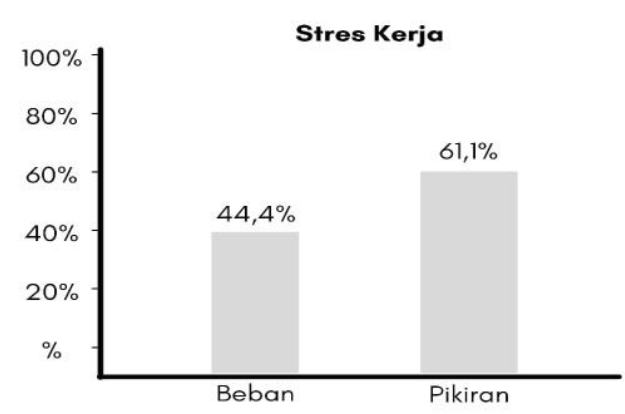

Berdasarkan tabel kesimpulan diatas, diperoleh skor persentase tertinggi dari masing masing indikator variabel stres kerja antara lain, indikator beban sebesar 44,4,9\%, dan pikiran $61,1 \%$. Maka dapat disimpulkan persentase tertinggi berada pada indikator pikiran dengan nilai sebesar 61,1\%, dimana karyawan di PT. Permodalan Nasional Madani Mekaar yang mengalami stres kerja merupakan orang yang memiliki pikiran kurang stabil pada saat melakukan pekerjaanya.

\section{Hiptoesis Statistik :}

Berikut ini adalah beberapa hasil dari Uji Hipoesis Statistik dalam penelitian ini:

1. $\mathbf{H}_{\mathbf{0}}$ : Kepribadian Introvert tidak berpengaruh terhadap stres kerja pada karyawan PT. Permodalan Nasional Madani Mekaar.

2. $\mathbf{H}_{\mathbf{a}}$ : Kepribadian Introvert berpengaruh terhadap Stres Kerja pada karyawan PT. Permodalan Nasional Madani Mekaar.

Tabel 5. Pengaruh Kepribadian Introvert (X) Terhadap Stres Kerja (Y)

\begin{tabular}{|c|c|c|c|c|c|c|}
\hline $\begin{array}{c}\text { Variabe } \\
\mathbf{l}\end{array}$ & $\mathbf{R}$ & $\mathbf{t}_{\text {titum }}$ & $\mathbf{t}_{\text {tabel }}$ & $\begin{array}{c}\text { Hasil } \\
\text { Keputusan }\end{array}$ & $\begin{array}{c}\text { Koefisien } \\
\text { Determinasi }\end{array}$ & $\begin{array}{c}\text { Derajat } \\
\text { Pengaruh }\end{array}$ \\
\hline $\mathrm{Xdan} \mathrm{Y}$ & 0,266 & 1,609 & 2,032 & $\begin{array}{c}\mathrm{H}_{0} \text { Diterima, } \\
\mathrm{H}_{3} \text { Ditolak }\end{array}$ & $7,1 \%$ & $\begin{array}{c}\text { Sangat } \\
\text { Kecil }\end{array}$ \\
\hline
\end{tabular}

Dari tabel hasil analisis statistik diatas, dapat diketahui bawa besarnya nilai korelasi atau hubungan (R) antara kepribadian introvert dengan stres kerja adalah 0,266. Dari output tersebut diperoleh koefisien determinasi (R Square) sebesar 0,071 atau sebesar 7,1\% yang mengandung arti bahwa pengaruh Kepribadian Introvert terhadap Stres Kerja adalah sebesar 7,1\%, dan dapat dikatakan pengaruhnya sangat lemah. Sedangkan sisanya 92,9\% dipengaruhi oleh faktor lain yang tidak diteliti dalam penelitian ini seperti konflik kerja, beban kerja, lingkungan kerja dan gaya kepemimpinan.

Kemudian diperoleh hipotesis yang diajukan yaitu menerima $\mathrm{H}_{0}$ dan menolak $\mathrm{H}_{\mathrm{a}}$ yang menyatakan bahwasannya ada pengaruh kepribadian introvert terhadap stres kerja, dari hasil analisis data tersebut memang menunjukan adanya pengaruh, akan tetapi kecil yaitu sebesar $7,1 \%$, artinya faktor yang mempengaruhi stres kerja dari kepribadian introvert tersebut sangatlah kecil, sehingga dianggap tidak berpengaruh. Hal ini berdasarkan hasil uji t juga, variabel kepribadian introvert diperoleh nilai thitung $=1,609<2,032=$ ttabel, dan signifikansi 0,117 $>$ 0,05, maka artinya menerima $\mathrm{H} 0$ dan menolak Ha, Artinya variabel kepribadian introvert memiliki pengaruh positif tapi tidak signifikan terhadap stres kerja pada karyawan, hal ini dikarenakan memang seorang introvert pendiam pada saat berkomunikasi dengan oranglain, akan tetapi sikapnya aktif pada saat bekerja karena ia sangat fokus dalam melakukan pekerjaanya tersebut. 


\section{Kesimpulan}

Berdasarkan hasil penelitian dan pembahasan yang telah dilakuan mengenai Pengaruh Kepribadian Introvert terhadap Stres Kerja pada Karyawan PT. Permodalan Nasional Madani Mekaar dapat ditarik kesimpulan sebagai berikut :

1. Karyawan di PT. Permodalan Nasional Madani Mekaar yang berkepribadian introvert menyatakan bahwa komunikasi mereka dengan karyawan lainnya biasa saja ditempat kerja. Hal ini terbukti pada saat observasi di lapangan, terlihat komunikasi dari 19 responden atau 52,8\% tersebut biasa saja, yang artinya terkadang lancar ataupun kaku dalam berkomunikasi, karena hal ini tergantung topik pembicaraan dalam komunikasi di tempat kerja tersebut.

2. Karyawan di PT. Permodalan Nasional Madani Mekaar yang mengalami stres kerja merupakan orang yang memiliki pikiran kurang stabil pada saat melakukan pekerjaanya. Hal ini terbukti pada saat observasi di lapangan, terlihat 22 responden atau $61,1 \%$ tersebut memiliki pikiran yang kurang stabil dikarenakan pekerjaannya tidak selesai dengan tepat waktu, ditambah banyaknya pekerjaan yang harus diselesaikan dengan batas waktu yang terbatas, sehingga mengakibatkan dirinya tidak bisa fokus dan membuat pikirannya menjadi kurang stabil.

3. Kepribadian Introvert berpengaruh positif tapi tidak signifikan terhadap Stres Kerja, tidak signifikan. Akan akan tetapi pengaruhnya hanya sebesar 7,1\%, artinya faktor yang mempengaruhi stres kerja dari kepribadian introvert tersebut sangatlah kecil, sehingga dianggap tidak berpengaruh. Hal ini berdasarkan hasil uji t juga, dari variabel kepribadian introvert diperoleh nilai thitung $=1,609<2,032=$ ttabel, yang artinya tidak ada pengaruh yang signifikan antar variabel dan nilai signifikansi $0,117>0,05$ yang menyatakan tidak berpengaruh signifikan pula, maka artinya H0 diterima dan Ha ditolak. Kemudian dikatakan tidak signifikan dikarenakan memang seorang introvert pendiam pada saat berkomunikasi dengan oranglain, akan tetapi sikapnya aktif pada saat bekerja karena ia sangat fokus dalam melakukan pekerjaanya tersebut.

\section{Acknowledge}

Segala puji dan syukur kepada Allah SWT penulis panjatkan karena berkat rahmat dan karuniaNya penulis dapat menyelesaikan penelitian ini. Tak lupa shalawat serta salam senantiasa kita curahkan kepada Nabi Muhammad SAW, beserta keluarga dan para sahabatnya. Oleh karena itu, pada kesempatann ini dengan segala kerendahan hati penulis ingin mengucapkan banyak terimakasih atas bantuan doanya kepada :

1. Allah SWT yang telah melancarkan segala urusan yang berkaitan dengan proses penyusunan penelitian ini.

2. Orang tua yang sangat saya sayangi dan saya cintai, Ibu Euis Nurhayati dan seluruh keluarga besar saya yang telah menjadi inspirasi saya untuk menggapai cita-cita.

3. Bapak Dr. Rusman Frendika, SE., MM dan Bapak Firman Shakti, S.H.I,. M.Msc., PhD selaku dosen pembimbing yang telah bersedia memberikan waktu dan tenaga untuk membimbing dan mengarahkan penulisan dalam penyusunan penelitian ini.

4. Mbak Wulansari selaku kepala cabang dari pihak PT. PNM Mekaar yang sudah memperbolehkan saya melakukan penelitian ini.

5. Semua orang yang tidak bisa saya sebutkan satu persatu, yang telah membantu penulis untuk dapat menyelesaikan skripsi ini.

\section{Daftar Pustaka}

[1] Dimitru, \& Cozman. (2012). The Relationship Between Stress and Personality. International Journal of the Bioflux Society, 4 (1), 36.

[2] Eysenck, H. (1969). Teori Kepribadian Introvert. New York.

[3] Eysenck, H. (1969). Indikator Tipe Kepribaian Introvert. Jakarta: CV Sehat.

[4] Humphrey. (1999). Teori dan Indikator Stress Kerja.

[5] Jung, C. G. (1978). Tipe Kepribadian Secara Panjang Lebar. New York: John Wilons, Inc. 
[6] Permodalan Nasional Madani. (2020, Desember 24). PNM (Permodalan Nasional Madani). Diambil kembali dari pnm.co.id: https://www.pnm.co.id/

[7] Rivai, \& Sagala. (2011). Pengaruh Beban Kerja Dan Lingkungan Kerja Terhadap Stres Kerja Karyawan Pada Pt Pln (Persero) Wilayah Sulawesi Selatan Tenggara Dan Barat Sektor Pembangkitan Bakaru Pusat Listrik Bakaru. Diambil kembali dari journal.uin-alauddin.ac.id: www.journal.uin-alauddin.ac.id

[8] Szilagyi. (1990). Kajian Teori Stress Kerja. Diambil kembali dari etheses.uin-malang.ac.id: etheses.uin-malang.ac.id 